\title{
Forage removal and grazing time of cattle on small paddocks
}

\author{
ROBERT C. BROWELEIT, WALTER H. SCHACHT, BRUCE E. ANDERSON, AND ALEXANDER J. SMART
}

Authors are former graduate assistant, associate professor, professor, and technologist, Department of Agronomy, P.O. Box 830915, University of Nebraska, Lincoln, Neb. 68583-0915.

\begin{abstract}
Animals used in grazing trials with small paddocks usually have not been exposed to the experimental site and related research procedures. Grazing trials conducted in May and August 1996 on smooth bromegrass (Bromus inermis Leyss.) quantified forage removal and grazing time of heifers adapted or not adapted to small paddocks. Treatments consisted of adapting heifers for 4 days to small paddocks $(0.054$ ha) and a control treatment of heifers continuously stocked in larger paddocks (>16 ha). On day 5, each group of heifers was moved to similar small paddocks and forage utilization and cattle grazing times were measured after 4 and 24 hours of grazing. In May, when sward structure was comparable in the large and small paddocks, tiller height reduction, leaf length reduction, herbage biomass reduction, and grazing time were similar $(P>0.10)$ for experienced and inexperienced heifers after 4 and 24 hours of exposure to day-5 paddocks. In August, when sward structure differed between the large and small paddocks, leaf length reduction after 4 hours was greater $(P<0.10)$ by experienced cattle than inexperienced cattle. Herbage reduction in August by experienced cattle was $435 \mathrm{~kg} \mathrm{ha}^{-1}$ greater $(P<0.05)$ than by inexperienced cattle after 24 hours. Cumulative grazing time was 76 minutes $(P<0.10)$ greater at 4 hours for the experienced cattle than the inexperienced cattle. Grazing animals appear to adapt immediately to small paddocks but other unfamiliar grazing conditions, e.g., sward structure, may require short adaptation periods for experimental animals.
\end{abstract}

Key Words: grazing trials, ingestive behavior, sward structure

Reliability of information from grazing management research depends in part on the ingestive behavior of the experimental animals. Grazing trials commonly are conducted in small paddocks $(<0.5$ ha) with high stock densities and short grazing periods (Binnie and Chestnutt 1991, Howard et al. 1992, Forbes and Coleman 1993). Small paddocks greatly reduce logistic and funding requirements and allow researchers to implement studies in which confounding variables can be controlled more effectively. Investigators generally assume that ingestive behavior of grazing animals is not affected by paddock size, periodic movement in and out of small paddocks, or experience with different sward

\footnotetext{
Authors thank Dr. J. Gosey and Dr. J. Kinder, UNL Animal Science Department, for providing animal and land resources.

Published as journal article 12311, Agriculture Research Division, University of Nebraska.

Manuscript accepted 19 Aug. 1999.
}

\section{Resumen}

Los animales utilizados en experimentos de apacentamiento con potreros pequeños usualmente no han sido expuestos al sitio experimental y los procedimientos de investigación relacionados. En ensayos de apacentamiento, conducidos en mayo y agosto de 1996 en praderas de "Smooth bromegrass" (Bromus inermis Leyss.), se cuantifico la remoción de forraje y el tiempo de apacentamiento de vaquillas adaptadas y no adaptadas a potreros pequeños. Los tratamientos consistieron en adaptar las vaquillas a potreros pequeños $(0.54$ ha) durante un periodo de 4 días y un tratamiento control de vaquillas que habían apacentado continuamente en potreros grandes (> 16 ha). En el día 5, cada grupo de vaquillas se movió a potreros pequeños similares y después de 4 y 24 horas de apacentamiento se midió la utilización de forraje y los tiempos de apacentamiento. En Mayo, cuando la estructura de la pradera fue similar en los potreros grandes y pequeños, la reducción de altura de los hijuelos, la reducción de la longitud de las hojas, la reducción de biomasa del forraje y el tiempo de apacentamiento fueron similares $(P>0.01)$ tanto para las vacas experimentadas como las vaca inexpertas a las 4 y 24 horas de exposición en el día 5. En Agosto, cuando la estructura de la pradera difirió entre los potreros grandes y pequeños, la reducción de la longitud de la hoja a las 4 horas fue mayor $(P<$ 0.10) con el ganado experimentado que con el ganado inexperto. Después de 24 horas, la reducción de forraje por el ganado experimentado fue $435 \mathrm{~kg} \mathrm{ha}^{-1}$ mayor $(P<0.01)$ que la reducción ocasionada por el ganado sin experiencia. A las 4 horas, el tiempo acumulado de apacentamiento del ganado experimentado fue 76 minutos $(P<0.01)$ mayor que el tiempo del ganado inexperto. Los animales en apacentamiento parecen adaptarse inmediatamente a los potreros pequeños, pero ante otras condiciones de apacentamiento desconocidas, por ejemplo, la estructura de la pradera, los animales experimentales puede requerir de pequeños periodos de adaptación.

structures. As a consequence, animals used in trials with small paddocks often lack experience or adaptation to grazing conditions in small paddocks. Various researchers (Forbes and Hodgson 1985, Bailey et al. 1989, Dougherty et al. 1992, Krysl and Hess 1993) have questioned experimental procedures that do not allow for exposure of animals to conditions unique to the experimental design prior to initiation of a grazing trial.

Information is lacking on grazing animal response to small experimental paddocks that could influence results. The objective of this study was to quantify forage removal and grazing time of cattle that were either adapted or not adapted to small paddocks (0.054 ha). 


\section{Study Site}

Research was conducted at the University of Nebraska's Agricultural Research and Development Center, located $45 \mathrm{~km}$ northeast of Lincoln, Neb. $\left(41^{\circ} 10^{\prime} \mathrm{N}, 96^{\circ} 25^{\prime} \mathrm{W}\right)$ at an elevation of 350 $\mathrm{m}$. Soils are Sharpsburg silty clay loams (fine smectitic mesic Typic Argiudolls) derived from loess materials and with 0 to $2 \%$ slopes. The climate is continental. Long-term average annual precipitation at the research site is $68 \mathrm{~cm}$ with $50 \mathrm{~cm}$ as rain during the growing season from 1 April to 30 September. Annual precipitation in 1996 was $69 \mathrm{~cm}$ with $57 \mathrm{~cm}$ coming during the growing season.

The study was conducted in a 2-ha, rectangular pasture with a smooth bromegrass (Bromus inermis Leyss.) monoculture and bordered by 4 rows of mature, eastern redcedar (Juniperus virginiana L.) trees on the north and south perimeters. The experimental site was cut for hay in 1995 and fertilized on 23 February 1996 with ammonium nitrate (34-0-0) at $18 \mathrm{~kg} \mathrm{~N} \mathrm{ha}^{-1}$. Pretrial management resulted in a rapidly growing sward that was free of standing dead residue in spring 1996. Six small paddocks ( $0.054 \mathrm{ha})$ were fenced at each end of the 2-ha pasture. Hereafter, these paddocks are referred to as day -5 paddocks. Distance between these 2 sets of paddocks was a minimum of $300 \mathrm{~m}$.

\section{Methods}

Two grazing trials, each lasting 18 days, were conducted from 7 to 24 May (Trial 1) and 31 July to 16 August 1996 (Trial 2). Each trial was a randomized complete block design with cattle allotted to 6 replications of 2 treatments consisting of animals experienced or inexperienced with daily rotation among small paddocks. Source of cattle was a herd of 48 yearling heifers of MARC III breeding (1/4 Hereford, 1/4 Angus, 1/4 Red Poll, and $1 / 4$ Penzguaer). The heifers were born in spring 1995 and had grazed the surrounding pastures of smooth bromegrass, ranging from 16 to 25 ha in area, since birth.

On the first day of each 18-day trial, heifers were allocated randomly in groups of 8 to the 6 replications and kept in separate pastures of 16 ha or larger. Following the first day, a new replication of animals was selected randomly every other day to begin a 4-day adaptation period. Four of 8 heifers per replication were left in their assigned larger paddock until day 5 . The other 4 heifers were moved to adaptation paddocks and rotated daily through 1 of 6 sets of 4 ungrazed, contiguous 0.054-ha paddocks that were isolated from the day5 paddocks. At 0700 hours on day 5 , the 2 treatment groups were placed at opposite ends of the 2-ha pasture in the day-5 paddocks. Each group remained in its respective paddock until 0700 hours of day 6 when they were moved off the study site. All plant and animal data used to determine heifers response to adaptation were collected in the day-5 paddocks.

Starting date for each replication of heifers was staggered to maintain treatment independence and avoid social interaction among treatment groups while in the day-5 paddocks. The adaptation paddocks were out-of-sight of the day-5 paddocks either south of the redcedar rows or in the area between the day-5 paddocks. Overall, the experimental protocol assured minimal disturbance of the experimental animals caused by animal movement or proximity to other groups of grazing animals. Similar trials conducted in 1995 on warm-season, tallgrass pasture (Broweleit 1997) indicated that proximity of treatment groups to each other likely affects ingestive behavior.

At the initiation of Trial 1, swards in all paddocks were similar and in a vegetative stage of growth. Smooth bromegrass grew rapidly during Trial 1 and swards progressed from an early elongation stage to a 3 -node stage by the end of Trial 1. Average tiller height and leaf length at the beginning of Trial 1 (10 May) was 27 and $59 \mathrm{~cm}$, respectively. By the end of Trial 1, mean tiller height and leaf length was 44 and $72 \mathrm{~cm}$, respectively.

Trial 2 exposed cattle to a structurallyunique sward in small paddocks. The monoculture of smooth brome in the day- 5 and adaptation paddocks was mowed to a height of approximately $20 \mathrm{~cm}$ in June 1996, and then allowed to regrow until August. The sward consisted of new tillers that initiated after mowing and a layer of stubble about $20 \mathrm{~cm}$ tall. The larger pastures grazed by the inexperienced animals until day 5 of a grazing period had not been mowed and lacked the stubble layer.

Live weight of cattle averaged $308 \mathrm{~kg}$ head $^{-1}( \pm 11.9 \mathrm{~kg})$ and $343 \mathrm{~kg}$ head $^{-1}( \pm 9.3$ $\mathrm{kg}$ ) for Trials 1 and 2, respectively. Mean standing crop biomass, on a dry matter (DM) basis, at the beginning of Trial 1 was $3,690 \mathrm{~kg} \mathrm{ha}^{-1}( \pm 139 \mathrm{~kg})$. Standing crop was estimated by clipping vegetation at ground level from 20 quadrats $\left(0.56 \mathrm{~m}^{2}\right)$ randomly located across the day- 5 paddocks. Clipped samples were dried at $65^{\circ} \mathrm{C}$ to a constant weight in a forced-air oven, and weighed. Herbage allowance was $74 \mathrm{~kg}$ DM per animal unit day $\left(\mathrm{AUD}^{-1}\right)$ and stocking density was 75 yearlings $\mathrm{ha}^{-1}$. At the beginning of Trial 2, mean standing crop biomass was $4,180 \mathrm{~kg} \mathrm{ha}^{-1}( \pm 152 \mathrm{~kg})$. Of the available standing crop in Trial 2, an estimated $30 \%$ was vegetative regrowth and $70 \%$ consisted of stubble that remained following mowing in June. Allowance of vegetative regrowth was about $22.55 \mathrm{~kg} \mathrm{DM} \mathrm{AUD}^{-1}$. These sward composition estimates were determined at the beginning of Trial 2 by the same quadrat method as used in Trial 1. Tillers from the clip samples were hand separated into vegetative regrowth and stubble fractions before drying and weighing.

All heifers in Trial 1 were implanted with norgestomet (Merial Limited, Iselin, N.J.) at the initiation of the 4-day adaptation period of each replication to reduce reproductive function and estrous activity during the trial. Heifers used in Trial 2 were in their first trimester of pregnancy and did not exhibit estrous behavior. Heifers used on both grazing trials were accustomed to handling as would be typical on many experiment stations. Efforts were made during the months prior to the trials to minimize the number of times these animals were taken off pasture and placed in corrals. All supplemental feeding had ceased 21 days prior to initiation of Trial 1.

At the beginning of each 4-day adaptation period, 2 heifers were selected randomly from each treatment group, fitted with 8-day vibracorders (Stobbs 1970, Walker and Heitschmidt 1989), and allowed to adapt to the vibracorders until day 5 when grazing time was measured. Data from the recording disc in a vibracorder were interpreted as to the amount of total grazing time within each 30 minute period. Grazing time for contiguous sets of 2-hour intervals up to 24 hours were summed on day 5 to compute cumulative grazing time. Interval grazing time was based on amount of grazing time in each 2-hour period within the 24 hours on day 5 and was used to determine when grazing time responses occurred.

Tiller height reduction and leaf lamina length reduction of smooth bromegrass on day 5 were estimated based on measuring 60 marked tillers in each paddock. On day 4 of each grazing period, 20 tillers were located along each of three, $20-\mathrm{m}$ transects in each day-5 paddock. Tillers were marked with colored wire and tiller height and total length of leaf lamina were measured. Tiller height was measured from the base of the tiller at ground level to the 
highest point on the tiller with leaves extended upward (Briske and Stuth 1982). Leaf lamina length was measured from the tip of the leaf blade to the collar of each leaf (Curll and Wilkins 1982). Measurements were taken again at 4 and 24 hours after movement into the day-5 paddocks. Marked tillers in Trial 2 were classified as either stubble or vegetative regrowth and were located alternately along 3 transects in each day-5 paddock.

Herbage removal by the grazing animals was estimated by clipping standing crop biomass in 8 large quadrats using a flail harvester before and after 24 hours of grazing in each of the day-5 paddocks (Matches 1966). Quadrat size was $0.9 \mathrm{~m}$ wide and quadrat length was variable but averaged $3.0 \mathrm{~m}$. The length of each quadrat was measured immediately after clipping. Clipping height was about 10 $\mathrm{cm}$. Subsamples were taken of the harvested material and dried at $65^{\circ} \mathrm{C}$ in a forcedair oven to a constant weight to estimate DM yields of the herbage.

Data were analyzed using the Statistical Analysis System (SAS Institute 1994) generalized linear models (GLM) procedures. The experimental unit was the day5 paddock. Treatment means from each day-5 paddock for tiller height reduction, leaf lamina reduction, grazing time, and herbage biomass reduction were used as observations for the analysis, and were evaluated separately by analysis of variance using a randomized complete block design. A separate analysis of variance was conducted on data for each trial. When significant treatment differences $(\mathrm{P}$ $<0.10)$ were indicated by F-tests, treatment means were compared using least significant differences.

\section{Results and Discussion}

\section{Trial 1}

Tiller height reduction by experienced and inexperienced cattle in the day-5 paddocks did not differ in Trial 1 at 4 hours $(\mathrm{P}$ $=0.46)$ or at 24 hours $(\mathrm{P}=0.31$; Table 1$)$. Leaf lamina length reduction also was not different between treatments at either 4 hours $(P=0.64)$ or 24 hours $(P=0.42)$. There was no treatment difference $(\mathrm{P}=$ 0.26 ) in reduction of standing herbage biomass over the 24-hour period. Grazing times did not differ between treatments for either cumulative grazing time $(\mathrm{P}=0.97)$ or for any of the 2-hour intervals ( $\mathrm{P}>$ 0.10; Fig.1).

Cattle adapted readily to small paddocks when sward structure was homogeneous and similar to previous grazing conditions.

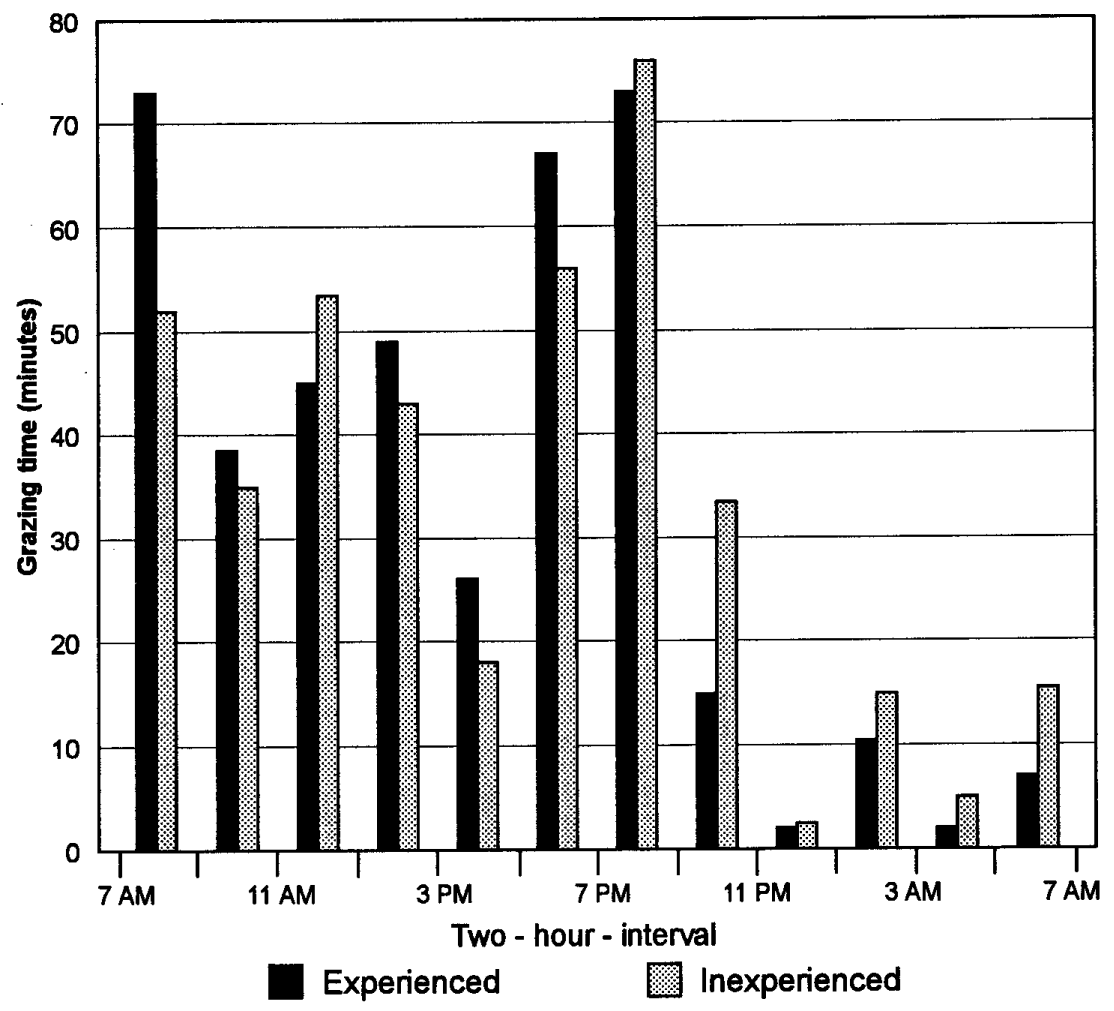

Fig. 1. Grazing time in 2-hour intervals for a 24-hour period beginning at 0700 hours on day 5 for heifers experienced or not experienced with small paddocks in May 1996. There were no differences $(P>0.10)$ between treatment means for any intervals during the 24-hour period.
Growing conditions during Trial 1 favored rapid vegetative growth of the bromegrass sward that was similar for both the day 1 through day 4 small paddocks grazed by the experienced heifers and the larger pastures where the inexperienced cattle grazed from day 1 through 4 . Herbage allowance also was relatively high $(72 \mathrm{~kg}$ $\mathrm{DM} \mathrm{AUD}^{-1}$ ) which provided an abundance of good quality forage.

\section{Trial 2}

In Trial 2, tiller height $(\mathrm{P}=0.11)$ and leaf lamina length $(\mathrm{P}=0.07)$ were reduced more in the first 4 hours on the day- 5 paddocks by experienced than by inexperienced heifers (Table 1). The 24-hour measurements of these variables, however, were not different $(\mathrm{P}=0.14$ and $\mathrm{P}=0.34$, respectively) between treatments (Table $2)$. Experienced heifers removed more $(\mathrm{P}$ $=0.03$ ) standing herbage biomass after 24 hours of grazing than did inexperienced heifers.

Tiller height $(\mathrm{P}=0.027)$ and leaf lamina length $(P=0.006)$ were reduced more on vegetative regrowth tillers than on stubble tillers after 24 hours of grazing (Table 2).
Table 1. Mean reduction $( \pm \mathrm{SE})$ in tiller height, leaf lamina length, and standing herbage biomass in a smooth bromegrass pasture grazed by heifers experienced or not experienced with the grazing environment in May 1996 (Trial 1) and August 1996 (Trial 2).

\begin{tabular}{|c|c|c|c|c|c|}
\hline \multirow{3}{*}{ Treatment } & \multicolumn{4}{|c|}{ Reduction } & \multirow{3}{*}{$\frac{\text { Biomass }}{24 \mathrm{~h}}$} \\
\hline & \multicolumn{2}{|c|}{ Tiller height } & \multicolumn{2}{|c|}{ Leaf lamina length } & \\
\hline & $4 \mathrm{~h}$ & $24 \mathrm{~h}$ & $4 \mathrm{~h}$ & $24 \mathrm{~h}$ & \\
\hline & ----------- & $-----(c$ & . & "----- & ---- $\left(\mathrm{kg} \mathrm{ha}^{-1}\right)---$ \\
\hline \multicolumn{6}{|l|}{ Trial 1} \\
\hline Experienced & $2.1^{\mathrm{a}} \pm 0.46$ & $8.2^{\mathrm{a}} \pm 1.05$ & $7.1^{\mathrm{a}} \pm 1.34$ & $27.0^{\mathrm{a}} \pm 3.17$ & $617^{\mathrm{a}} \pm 147$ \\
\hline Not experienced & $1.6^{\mathrm{a}} \pm 0.46$ & $6.1^{\mathrm{a}} \pm 0.43$ & $6.1^{\mathrm{a}} \pm 1.85$ & $23.7^{\mathrm{a}} \pm 1.51$ & $872^{a} \pm 236$ \\
\hline \multicolumn{6}{|l|}{ Trial 2} \\
\hline Experienced & $3.4^{\mathrm{a}} \pm 0.77$ & $6.8^{\mathrm{a}} \pm 1.12$ & $9.6^{\mathrm{a}} \pm 1.79$ & $17.8^{\mathrm{a}} \pm 2.62$ & $972^{\mathrm{a}} \pm 164$ \\
\hline Not experienced & $1.7^{\mathrm{a}} \pm 0.49$ & $5.3^{\mathrm{a}} \pm 0.81$ & $5.0^{\mathrm{b}} \pm 1.49$ & $15.3^{\mathrm{a}} \pm 2.61$ & $537^{\mathrm{b}} \pm 196$ \\
\hline
\end{tabular}

${ }^{\mathrm{ab}}$ Different letters in a column within a trial indicate means are different $(\mathrm{P}<0.10)$. 
Table 2. Mean $( \pm$ SE) tiller height and leaf length reduction for vegetative regrowth and stubble tillers in smooth bromegrass paddocks grazed by heifers during August 1996 (Trial 2).

\begin{tabular}{|c|c|c|c|c|c|c|}
\hline Tiller type & $\begin{array}{l}\text { Beginning } \\
\text { tiller height }\end{array}$ & \multicolumn{2}{|c|}{ Tiller height reduction } & $\begin{array}{l}\text { Beginning } \\
\text { leaf length }\end{array}$ & \multicolumn{2}{|c|}{ Leaf length reduction } \\
\hline Vegetative regrowth & 19.8 & $3.0 \mathrm{a} \pm 0.33$ & $7.1 \mathrm{a} \pm 0.43$ & 43.8 & $9.0 \mathrm{a} \pm 0.96$ & $21.0 \mathrm{a} \pm 1.24$ \\
\hline
\end{tabular}

${ }^{\mathrm{ab}}$ Different letters in a column indicate means are different $(\mathrm{P}<0.10)$.

Differences between vegetative regrowth and stubble tillers after 4 hours of exposure to grazing were detected $(\mathrm{P}=0.068)$ only for leaf length. Both experienced and inexperienced heifers preferred the vegetative regrowth over the stubble as the vegetative regrowth tillers were defoliated most frequently $(\mathrm{P}<0.001)$. There was no interaction between treatment and tiller type as both experienced and inexperienced heifers defoliated marked tillers at similar frequencies $(\mathrm{P}>0.10)$.

During the first 2 hours (0700-0900 hours) following rotation onto the day-5 paddocks, experienced heifers spent 64 minutes more $(\mathrm{P}=0.002)$ time grazing than did inexperienced heifers (Fig. 2). For each remaining 2-hour interval of the

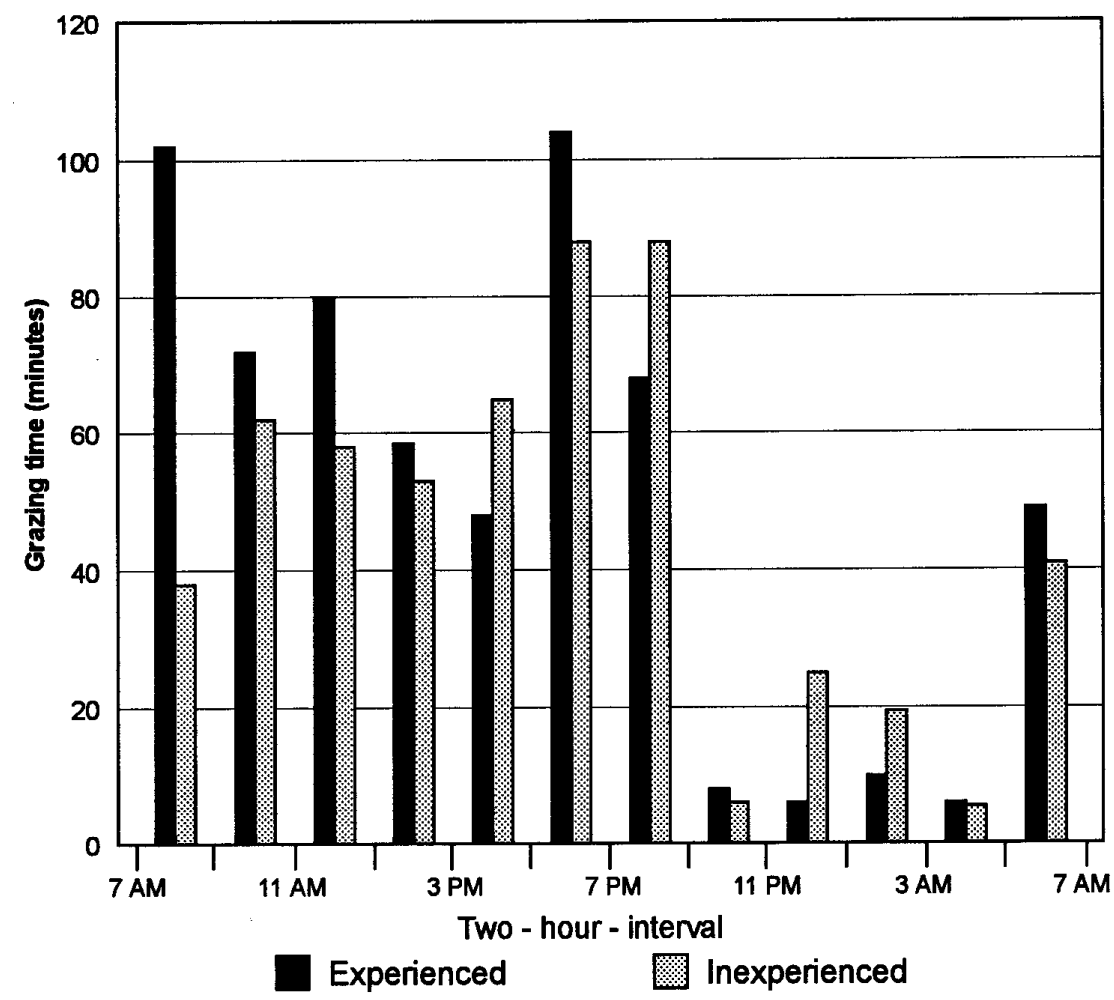

Fig. 2. Grazing time in 2-hour intervals for a 24-hour period beginning at 0700 hours on day 5 for heifers experienced or not experienced with small paddocks in August 1996. There was a difference $(P=\mathbf{0 . 0 0 2})$ between treatment means for the first 2 -hour interval $(0700$ to 0900 hours) only; grazing time in all other intervals were not different. Cumulative grazing time during the first 8 hours was higher $(P<0.10)$ for experienced than inexperienced heifers.
24 hours, grazing time for experienced and inexperienced heifers did not differ $(\mathrm{P}>$ $0.10)$. Although grazing time did not differ during any of the remaining 2-hour time intervals, cumulative grazing time over the first 8 hours was $50 \%$ greater $(\mathrm{P}<0.10)$ for the experienced heifers than for the inexperienced heifers. A minimum difference of 64 minutes in grazing time was maintained between treatments throughout the 24 hours; however, cumulative grazing time did not differ $(\mathrm{P}=0.33)$ from 8 hours into the trial until the end. Overall, the heifers adapted to novel conditions rapidly and 8 hours appeared to be adequate as an adaptation period for this unique sward; however, estimates of forage removal and grazing time were not collected beyond 24 hours.
Mean grazing time in Trial 2 was about 3 hours greater than in Trial 1 . Increased grazing time in Trial 2 may have been related to the relatively low availability of palatable forage. Mean biomass of standing herbage before grazing on the day-5 paddocks was $490 \mathrm{~kg} \mathrm{ha}^{-1}$ greater for Trial 2 than for Trial 1; however, $70 \%$ of the total biomass in Trial 2 consisted of dry, mature bromegrass stubble that was considerably less palatable than the green regrowth. Allowance of vegetative regrowth was relatively low $(22.5 \mathrm{~kg}$ DM $\mathrm{AUD}^{-1}$ ) in the small paddocks and may have resulted in a lower intake rate. Furthermore, the vibracorder method used to estimate grazing time did not discriminate between actual grazing time and search time (Stobbs 1970). We observed the heifers spending a high proportion of their time in Trial 2 with their heads down searching for palatable forage rather than continuously prehending forage. Jamieson and Hodgson (1979) and Hodgson (1981) also reported longer grazing times for cattle grazing stands of mature grass.

Differences in sward structure and forage allowance in Trial 2 were created by mowing spring growth in adaptation and day-5 paddocks after stem elongation was complete. The resulting layer of bromegrass stubble probably restricted grazing of the highly palatable young tillers that regrew after mowing, similar to the pseudostem barrier described by Barthram and Grant (1984). Until day 5, inexperienced cattle grazed in larger pastures where the sward consisted of smooth bromegrass that was allowed to regrow for 45 days following moderate spring defoliation through mid-June by mature cattle. The larger pastures were not altered by mowing prior to Trial 2. Treatment differences in the measured vegetation variables may have been due to the inability of inexperienced animals to adjust immediately to the unfamiliar sward structure and (or) low forage allowance within the small paddocks.

In summary, cattle readily adjusted to small paddocks in Trial 1 when forage resource characteristics were similar to those of the larger pastures and required 
only 8 hours in Trial 2 when sward structure in the small paddocks was unique and heterogeneous. Even though the cattle adapted readily to new grazing conditions, we concluded that an adaptation period should be used when research protocols involve novel grazing conditions and short grazing periods of 24 hours or less.

\section{Literature Cited}

Bailey, D.W., L.W. Rittenhouse, R.H. Hart, D.M. Swift, and R.W. Richards. 1989. Association of relative food availabilities and location by cattle. J. Range Manage. 42:480-482.

Barthram, G.T. and S.A. Grant. 1984. Defoliation of ryegrass-dominated swards by sheep. Grass Forage Sci. 39:211-219.

Binnie, R.C. and D.M.B. Chestnutt. 1991. Effect of regrowth interval on the productivity of swards defoliated by cutting and grazing. Grass Forage Sci. 46:343-350.

Briske, D.D. and J.W. Stuth. 1982. Tiller defoliation in a moderate and heavy grazing regime. J. Range Manage. 35:511-514.
Broweleit, R.C. 1997. Conditioning cattle to small paddocks and its effects on ingestive behavior. MS Thesis. Univ. Nebraska, Lincoln, Neb., pp. 103.

Curll, M.L. and R.J. Wilkins. 1982. Frequency and severity of defoliation of grass and clover by sheep at different stocking rates. Grass Forage Sci. 37:291-297.

Dougherty, C. T., N.W. Bradley, L.M. Lauriault, J.E. Arias, and P.L. Cornelius. 1992. Allowance- intake relations of cattle grazing vegetative tall fescue. Grass Forage Sci. 47:211-219.

Forbes, T.D.A. and J. Hodgson. 1985. Comparative studies of the influence of sward conditions on the ingestive behavior of cows and sheep. Grass Forage Sci. 40:69-77.

Forbes, T.D.A. and S.W. Coleman. 1993. Forage intake and ingestive behavior of cattle grazing old world bluestems. Agron. J. 85:808-816

Hodgson, J. 1981. Variations in the surface characteristics of the sward and the shortterm rate of herbage intake by calves and lambs. Grass Forage Sci. 36:49-57.
Howard, M. D., R.B. Muntifering, N.W. Bradley, G.E. Mitchell, Jr., and S.R. Lowrey. 1992. Voluntary intake and ingestive behavior of steers grazing Johnstone or endophyte infected Kentucky-31 tall fescue. J. Anim. Sci. 70:1227-1237.

Jamieson, W.S. and J. Hodgson. 1979. The effect of daily herbage allowance and sward characteristics upon the ingestive behaviour and herbage intake of calves under stripgrazing management. Grass Forage Sci. 34:261-271.

Krysl, L. J. and B.W. Hess. 1993. Influence of supplementation on behavior of grazing cattle. J. Anim. Sci. 71:2546-2555.

Matches, A.G. 1966. Sample size for mowerstrip sampling of pastures. Agron. J. 58:213-215.

SAS Institute Inc. 1994. SAS Users Guide: Statistics. (Version 6). SAS Inst., Inc., Cary, N.C. Stobbs, T.H. 1970. Automatic measurement of grazing time by dairy cows on tropical grass and legume pastures. Tropical Grassl. $4: 237-244$.

Walker, J.W. and R.K. Heitschmidt. 1989. Some effects of a rotational grazing treatment on cattle grazing behavior. J. Range Manage. 42:337-342.

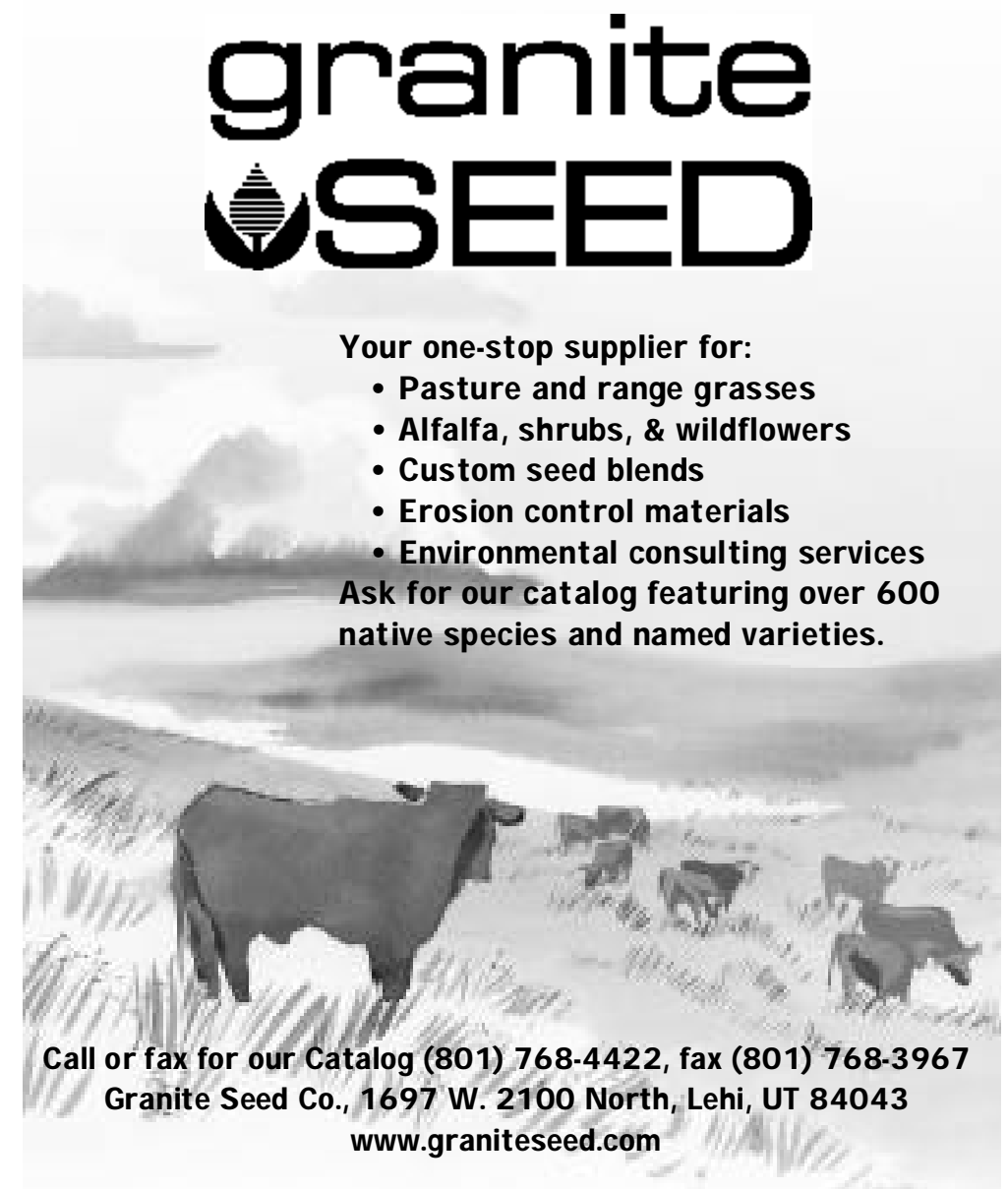

